\title{
U-PB DATING AND RB-SR ISOTOPE GEOCHEMISTRY OF THE EASTERN PORTION OF THE TRÊS CÓRREGOS BATHOLITH, RIBEIRA FOLD BELT, SÃO PAULO
}

\section{ANTONIO GIMENEZ FILHO ${ }^{1}$, VALDECIR DE ASSIS JANASI ${ }^{2}$, GINALDO ADEMAR DA CRUZ CAMPANHA ${ }^{2}$, WILSON TEIXEIRA ${ }^{2}$ AND LUIZ EMÍLIO TREVIZOLI JÚNIOR ${ }^{3}$}

\begin{abstract}
The ages of three facies of syn-orogenic metaluminous granites from the Três Córregos Batholith (Southern Ribeira Belt, São Paulo) were obtained by conventional U-Pb zircon dating. A typical porphyritic hornblende-biotite granite from the Saival massif yielded 605 $\pm 2 \mathrm{Ma}$. Two other samples of foliated granites show signs of inheritance, and no precise ages of crystallization were obtained. Their lowest ${ }^{207} \mathrm{~Pb} /{ }^{206} \mathrm{~Pb}$ ages, however, are only slightly discordant, and yield reliable upper limits that are, in both cases, around 608-610 Ma, demonstrating that these more deformed varieties are products of the same magmatic event that formed the bulk of the batholith, and not older orthogneisses, as admitted in some previous works. Calculated to the age of crystallization, the ${ }^{87} \mathrm{Sr} /{ }^{86} \mathrm{Sr}_{\mathrm{i}}$ ratios show a wide spread $(0.710$ to 0.717$)$. A clear negative correlation, in a batholith scale, with the $\mathrm{Sr}$ contents, is attributed to mixing with an old, high Rb/Sr mid-crustal component, and can explain the older isochronic ages typically obtained in these and similar granites. High ${ }^{87} \mathrm{Sr} /{ }^{86} \mathrm{Sr}$, high $\mathrm{Sr}$ mafic microgranular enclaves seem to point to a contribution from enriched sources in the continental mantle lithosphere to the Três Córregos magmatism.
\end{abstract}

Keywords: U-Pb dating, Rb-Sr isotope geochemistry, granite, Ribeira Fold Belt, Neoproterozoic.

INTRODUCTION Three huge $\left(>2,000 \mathrm{~km}^{2}\right)$ elongated granitic batholiths occur within the southern portion of the Ribeira Belt in the States of São Paulo and Paraná, Southeastern Brazil. They are, from west to east, the Cunhaporanga, Três Córregos and Agudos Grandes batholiths (Fig. 1). In view of their sizes, vast areas of these batholiths remain mapped only in reconnaissance scale. In recent years, however, detailed studies have been undertaken in selected portions of these batholiths, aiming the knowledge of their significance in the Neoproterozoic evolution of the Ribeira Belt (e.g., Janasi et al. 1990 Gimenez Filho 1993).

As typical of such large batholiths, a wide variety of granite types occur, with complex cross-cutting relations. In broad terms, the greatest part of the batholiths is made up of relatively mafic, porphyritic hornblende-biotite granitoids, often foliated and considered as "syn-tectonic" elongated bodies. More felsic, equigranular, pink granites crop out as circumscribed, elliptic to round-shaped plutons mostly forming marginal intrusions considered as " late-" or "posttectonic" to the Brasiliano orogeny. $\mathrm{Rb}-\mathrm{Sr}$ isotope studies on these batholiths in the last two decades (Gimenez Filho 1993, Reis Neto 1994, Leite 1997) yielded ages with large uncertainties for the more mafic "syn-orogenic" facies (due to the lack of $\mathrm{Rb} / \mathrm{Sr}$ scatter in such Sr-rich rocks, and in most cases also to variations in the ${ }^{87} \mathrm{Sr} /{ }^{86} \mathrm{Sr}$ initial ratios of different samples; see below). On the other hand, unrealistically young ages have been obtained in the felsic terms, a feature in some cases clearly related to hydrothermal loss of $\mathrm{Sr}$ (Gimenez Filho 1993, see also Vlach \& Cordani,1986).

This paper deals with the first U-Pb zircon ages of granites from the Três Córregos Batholith, determined on three samples representative of different "syn-orogenic" occurrences from its NE half, north of Apiaí, State of São Paulo. Previous studies in this region included faciological mapping on the 1:50,000 scale and geochemical and isotopic (K-Ar and $\mathrm{Rb}-\mathrm{Sr}$ ) dating of the granitic rocks (Gimenez Filho 1993, Gimenez Filho et al. 1995). On the light of the U-Pb ages here obtained, the $\mathrm{Rb}-\mathrm{Sr}$ data are reassessed and used as a tool to investigate some petrogenetic aspects of the magmatism.

GEOLOGY Regional The Neoproterozoic Ribeira Fold Belt (RFB) extends for ca. $1500 \mathrm{~km}$ in the NE-SW direction along the coastal areas of Southeastern Brazil. Its central and northern segments separate, in pre-drift reconstructions, the São Francisco and Congo Cratons. The southern segment is covered to the north by the Paleozoic and younger sedimentary rocks of the Paraná Basin that possibly overlie another stable area (the Paraná Craton of some authors) which was juxtaposed to the São Francisco Craton immediately prior to the development of the RFB (e.g., Ribeiro et al. 1995).

Low- to medium-grade supracrustal sequences, grouped in the Açungui Supergroup (e.g., Campanha \& Sadowski 1999), predominate in the southern segment of the RFB in the States of São Paulo and Paraná. The ages of deposition of these supracrustals have been subject of intense debate over the last decades. Arguments were raised for a
Mesoproterozoic as well as for a Neoproterozoic age of the different sequences, but most of the geochronological results are still a matter of dispute (Campanha \& Sadowski 1999). Plenty of radiometric data and geologic information, however, show that the major structural and metamorphic features, and that the bulk of the granitic magmatism in the RFB are products of the Neoproterozoic evolution.

The huge elongated batholiths dominated by porphyritic hornblende-biotite granites of high-K calc-alkaline affinities are considered to be the main products of "syn-orogenic" magmatism in the RFB. Several authors associate the genesis of these batholiths to a continental arc environment (e.g., Wernick et al. 1990, Janasi \& Ulbrich 1991, Gimenez Filho et al. 1995). The younger and smaller bodies made up of felsic and often undeformed granites are related to "post-orogenic" provinces developped under dominantly extensional regimes (cf. Janasi \& Ulbrich 1991).

Local The Três Córregos Batholith follows the main structural trend of the metamorphic units of the Southern RFB for over $200 \mathrm{~km}$. The $\mathrm{NE}$ and SW terminations of the batholith are covered by rocks of the Paraná Basin (Fig. 1).

The country rocks are mostly medium-grade metasedimentary rocks of the Água Clara Formation, a sequence dominated by calc-silicate rocks with local amphibolite intercalations. Higher-grade rocks, in part migmatitic, occur in a few areas, and are considered by some authors (cf. Gimenez Filho 1993) as a (Paleoproterozoic?) crystalline basement. The Itapirapuã fault zone separates the batholith from the Itaiacoca Group, a shalow water carbonate-dominated platform, to the west. East of the batholith, the Lajeado and Ribeira subgroups are interpreted as sequences deposited in progressively deeper water (Campanha \& Sadowski 1999).

Figure 2 is a geological map of the portion of the Três Córregos Batholith that was studied by Gimenez Filho (1993), who integrated previous maps on a 1:50,000 scale and performed petrographic, geochemical and isotopic analyses of the main granite types.

Four main granite types were included in the so-called "Três Córregos Complex": 1) augen-gneisses; 2) migmatites and anatectic granites; 3 ) foliated granites and 4) porphyritic granites (separated into the Barra do Chapéu, Saival, Córrego do Butiá, Capote, Lajeado and Paiol de Telha massifs). In some of the cited mapping surveys, the first three units were considered as parts of the crystalline basement, but further work demonstrated that at least unit 3 is a deformed variety of the porphyritic granites, of undisputed Neoproterozoic age.

MIGMATITIC GRANITES AND AUGEN GNEISSES These rocks occur in a small area at the western margin of the batholith (Fig. 2).

The augen gneisses are light-grey quartz diorites to quartz monzodiorites, with ca. $1 \mathrm{~cm}$ oval-shaped plagioclase megacrysts set in a matrix with quartz, plagioclase, traces of K-feldspar, biotite and hornblende, with accessory apatite, titanite, opaques and zircon and secondary carbonate and epidote. Dark, fine- to medium-grained,

1 - Divisão de Geologia, Instituto de Pesquisas Tecnológicas do Estado de São Paulo, Caixa Postal 0141, CEP 01064-970, São Paulo, SP, Brasil

2 - Instituto de Geociências, Universidade de São Paulo, Rua do Lago, 562 (Cidade Universitária) - CEP 05508-900 São Paulo, SP, Brasil

3 - Rua Bento da Cruz 553, CEP 16200-000, Birigüi, SP, Brasil 


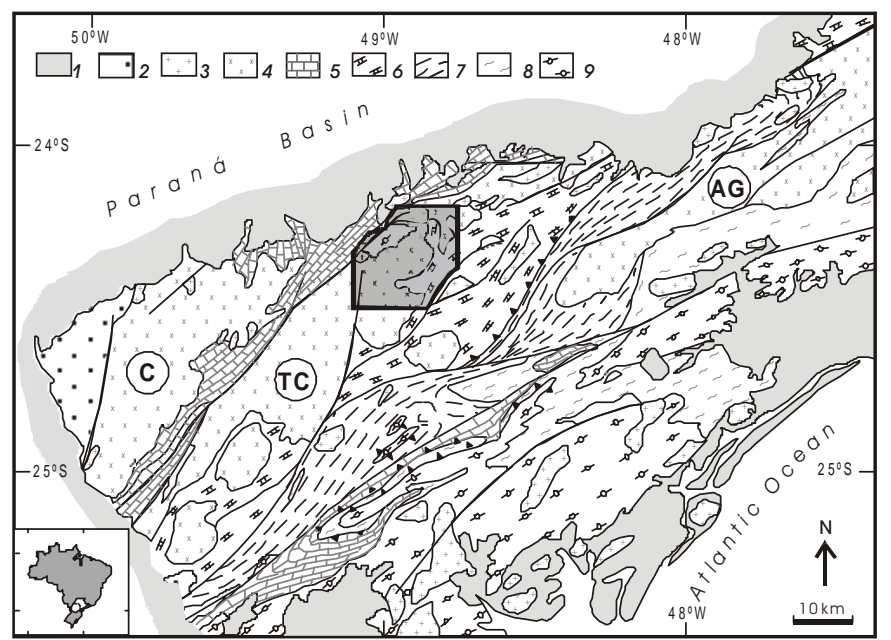

Figure 1-Geological sketch of part of the Ribeira Fold Belt in parts of the states of Paraná and São Paulo, Brazil, with location of the studied area. $1=$ Phanerozoic cover and intrusive rocks; $2=$ Late pull-apart basins; $3=$ postorogenic granites; $4=$ syn-orogenic granites (batholiths: $C=$ Cunhaporanga; $T C=$ Três Córregos; $A G=$ Agudos Grandes); 5 to $7=$ metasupracrustal rocks of the Açungui Supergroup; $8=$ schists of unknown origin; $9=$ gneissmigmatitic complex.

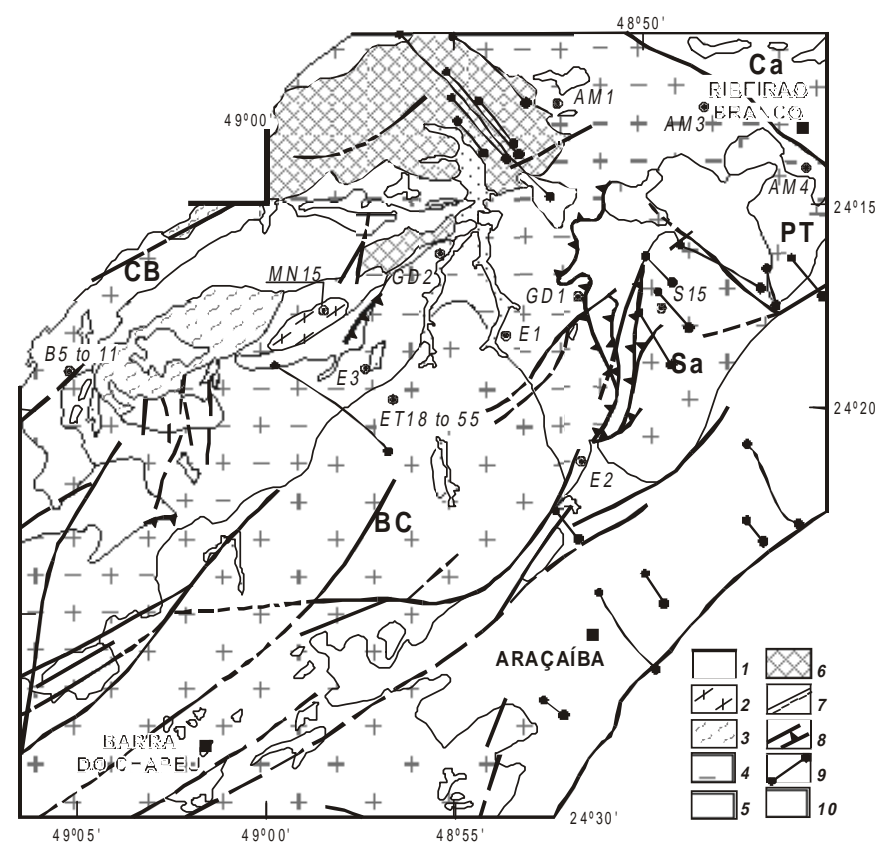

Figure 2- Geology of the eastern portion of the Três Córregos Batholith north of Apiaí, State of São Paulo, with location of the samples analysed for Rb-Sr and $U-P b$ isotopes. $1=$ metasedimentary rocks; $2=$ migmatitic granites; $3=$ augen gneisses; $4=$ foliated granites; $5=$ porphyritic granites; $6=$ post orogenic granites; $7=$ geologic contacts $; 8=$ faults $; 9=$ diabase dikes $; 10=$ alluvial deposits. $B C=$ Main massifs composed of syn-orogenic porphyritic granites: $B C=$ Barra do Chapéu; $C a=$ Capote; $C B=$ Córrego do Butiá; $S a=$ Saival; PT= Paiol de Telha. Sample locations: B5, ET18 etc.

foliated enclaves are locally abundant, and may show complex structures suggestive of an intimate interaction with the enclosing augen-gneisses.

The migmatitic granites are mostly heterogeneous, grey, equigranular biotite granites with abundant migmatitic structures, specially nebulitic and schlieren.

PORPHYRITIC GRANITES AND FOLIATED GRANITES Porphyritic hornblende-biotite granites with centimeter-sized (typically 3-4 cm) euhedral to oval-shaped K-feldspar megacrysts are the main rock types of the Três Córregos Batholith in the studied area. Modal analyses (Gimenez Filho et al. 1995) indicate the predominance of monzogranites, with variations to quartz monzonites and granodiorites. The color indices (IC) are typically in the range 10-15, but facies with IC as low as 5 are present in some massifs (e.g., Saival, Córrego do Butiá and Lajeado; Fig. 2). The accessory minerals are opaques (mostly magnetite), titanite, apatite and zircon. Secondary chlorite, muscovite, carbonate and epidote occur in some samples.

The foliated granites are in most cases deformed varieties of the porphyritic granites, occurring as border zones in some massifs or along zones of more intense deformation. The foliation is defined by the orientation of mafic minerals and locally by quartz and feldspar of the groundmass, and also of the eye-shaped pink K-feldspar megacrysts. The modes and mineralogy are the same as in the porphyritic granites, but the secondary minerals may be abundant in more deformed varieties. Leucocratic facies (pink gneissic granites with IC lower than 5) occur in some areas around the Barra do Chapéu massif (e.g., samples E-1, E-2 and E3, Fig. 2).

Mafic enclaves are common both in the porphyritic and in the foliated granites. They are fine-grained, dark grey, equigranular quartz diorites to quartz monzodiorites, and may show complex contacts with the enclosing granites, suggestive of interaction in a magmatic state.

POST-OROGENIC GRANITES Two main post-orogenic massifs occur in the area shown in figure 2. The Sguario massif is a zoned elliptical pluton with a wide border zone composed of a pink porphyritic to inequigranular, medium- to coarse-grained biotite syenogranite and a core of fine-grained, more felsic granite. The mafic and accessory minerals are brown biotite, in part transformed to chlorite, magnetite, titanite, zircon, apatite and allanite. Secondary minerals are sericite, epidote, chlorite, carbonate and fluorite. The smaller Correas massif is a satellite body south of the Sguario massif, and comprises evolved monzogranites with local topaz-bearing albite granite facies to which $\mathrm{Sn}$ - and $\mathrm{W}$-mineralized greisens are associated (Goraieb 1995).

\section{U-Pb GEOCRONOLOGY}

Analytical procedures

Samples chosen for analyses, weighing 8 to $10 \mathrm{~kg}$, were crushed in steel bar crushers and then sieved and separated into two size fractions (48-100 mesh and 100-270 mesh). The heavy minerals were concentrated from both fractions using a wiffle table at the Instituto de Pesquisas Tecnológicas (IPT). The separation of different magnetic fractions, crystal abrasion, dissolution, chemical separation and analysis of $\mathrm{Pb}$ and $\mathrm{U}$ was done at the Isotope Geochemistry Laboratory (IGL), University of Kansas, USA. Details of the analytical procedures used in the thermal ionization analysis of $\mathrm{U}$ and $\mathrm{Pb}$ isotopes at IGL are given in Janasi et al. (2000).

Results SAIVAL HORNBLENDE-BIOTITE GRANITE (SAMPLE S15) Sample S-15 is a porphyritic hornblende-biotite quartz monzonite from the Saival massif (Fig. 2). Four zircon fractions, each including six to twelve grains and weighing 0.008 to $0.027 \mathrm{mg}$, were chosen for analysis. All fractions are slightly discordant and have similar ${ }^{207} \mathrm{~Pb} /{ }^{206} \mathrm{~Pb}$ ages with no traces of inheritance (Table 1, Fig. 3). Fraction $\mathrm{m}(0)$ is concordant at $605 \pm 3 \mathrm{Ma}$. An average of the ${ }^{207} \mathrm{~Pb} /$ ${ }^{206} \mathrm{~Pb}$ ages of all four fractions, which is obtained as a discordia line with the lower intercept forced to zero, is here considered as the best estimate of the crystallization age of the rock, and yields $605.1 \pm 2.0$ Ma.

FOLIATED GRANITE (SAMPLE E-3) Sample E-3 is a leucocratic foliated granite from the border of the Barra do Chapéu massif.

Four zircon fractions consisting of 5 to 8 non abraded prismatic, transparent grains, were analysed. Fraction $\mathrm{m}(0)$, with the youngest ${ }^{207} \mathrm{~Pb} / 206 \mathrm{~Pb}$ age $(610 \pm 3 \mathrm{Ma})$ is the closest to concordance, and has the lowest error. Fraction $\mathrm{m}(+1)$ has clearly an inherited component, as shown by the ${ }^{207} \mathrm{~Pb} /{ }^{206} \mathrm{~Pb}$ age in excess of $670 \mathrm{Ma}$ (Table 1, Fig. 4). The other two fractions yield ${ }^{207} \mathrm{~Pb} /{ }^{206} \mathrm{~Pb}$ ages 5 to 10 Ma older than $\mathrm{m}(0)$. If all three are included in a regression forced to zero, a large uncertainty is associated with the age $(615 \pm 54$ Ma with MSWD = 12 ). We interpret that the old ages shown by fractions $n m(0)$ and $\mathrm{m}(+2)$ reflect a small inherited component, and that the ${ }^{207} \mathrm{~Pb} /{ }^{206} \mathrm{~Pb}$ age of fraction $\mathrm{m}(0)(610 \pm 3 \mathrm{Ma})$ places a reliable upper limit on the crystallization age of this sample. 
AUGEN-GNEISS (SAMPLE MN-15) Sample MN-15 is a quartz monzodioritic augen gneiss. As discussed above, this unit was separated from the rest of the Três Córregos batholith on the basis of its peculiar, more sodic composition, and on the presence of dioritic enclaves dated by $\mathrm{Rb} / \mathrm{Sr}$ at ca. $1.8 \mathrm{Ga}$ (Gimenez Filho 1993).

The four magnetic fractions dated consisted of 3 to 8 prismatic, transparent grains, and weighed 0.008 to $0.018 \mathrm{mg}$ each.

The large prismatic grains included in one of the $\mathrm{m}(-1)$ fractions are much more radiogenic than the others, and yield a very discordant result with a ${ }^{207} \mathrm{~Pb} /{ }^{206} \mathrm{~Pb}$ age of $1267 \pm 4 \mathrm{Ma}$ (Table 1$)$.

The remaining three fractions yield ${ }^{207} \mathrm{~Pb} /{ }^{206} \mathrm{~Pb}$ results in the same range observed for sample E-3 above (610-620 Ma). A regression forced to zero yields a similar age also with large and undesirable error $(611 \pm 43 \mathrm{Ma}$; MSWD = 7.8; Fig. 5). One of the fractions $(\mathrm{m}(+1))$ has a large analytical error and the other two are more discordant as

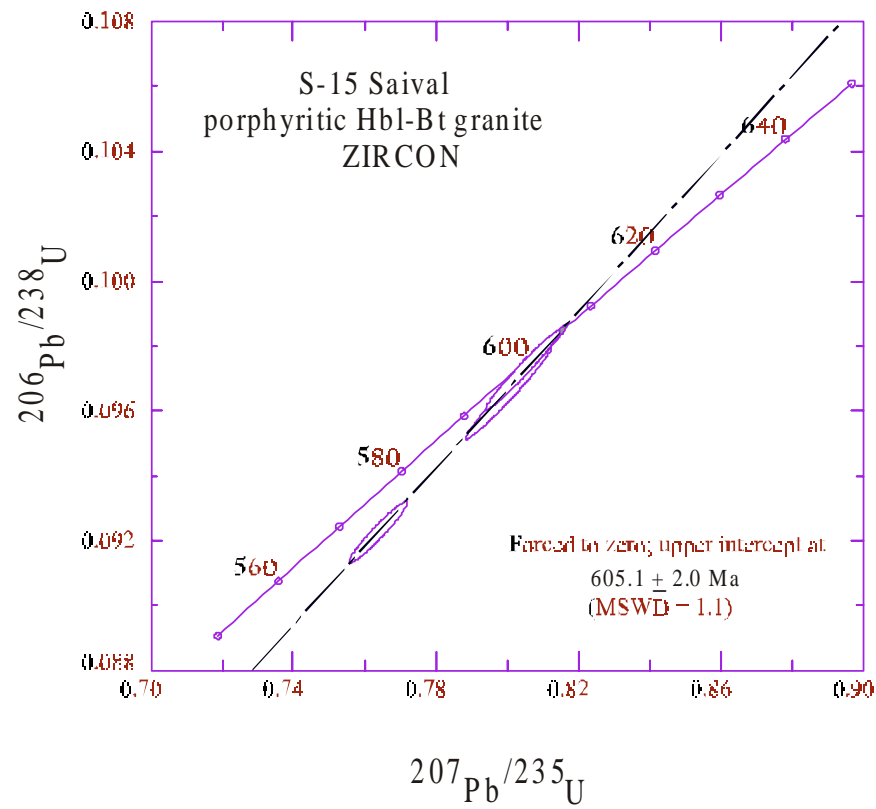

Figure 3- U-Pb concordia diagram with upper intercept calculated age for sample $S-15$. compared to E-3. We consider the youngest ${ }^{207} \mathrm{~Pb} /{ }^{206} \mathrm{~Pb}$ age yielded by fraction $\mathrm{m}(-1) \mathrm{b}(608 \pm 5 \mathrm{Ma})$ to place an upper limit on the crystallization age of this rock.

Forced to a lower intercept of $605 \mathrm{Ma}$, that is, admitting that all $\mathrm{Pb}$ loss occurred at the time of crystallization of the magma, the large crystals making up fraction $\mathrm{m}(-1)$ would have an upper intercept of $2095 \pm 42 \mathrm{Ma}$, pointing to a Transamazonian source for the inheritance (Fig. 5, inset).

Discussion Sample S-15 is a representative of the predominant rock-type making up the eastern half of the Três Córregos Batholith, and its $\mathrm{U}-\mathrm{Pb}$ results yield a reliable, precise age for the main period of granite generation in the area. The obtained age $(605 \pm 2 \mathrm{Ma})$ is younger than the $\mathrm{Rb}-\mathrm{Sr}$ and even some of the $\mathrm{K}-\mathrm{Ar}$ ages previously available for rocks of the batholith (cf. Souza 1990, Gimenez Filho

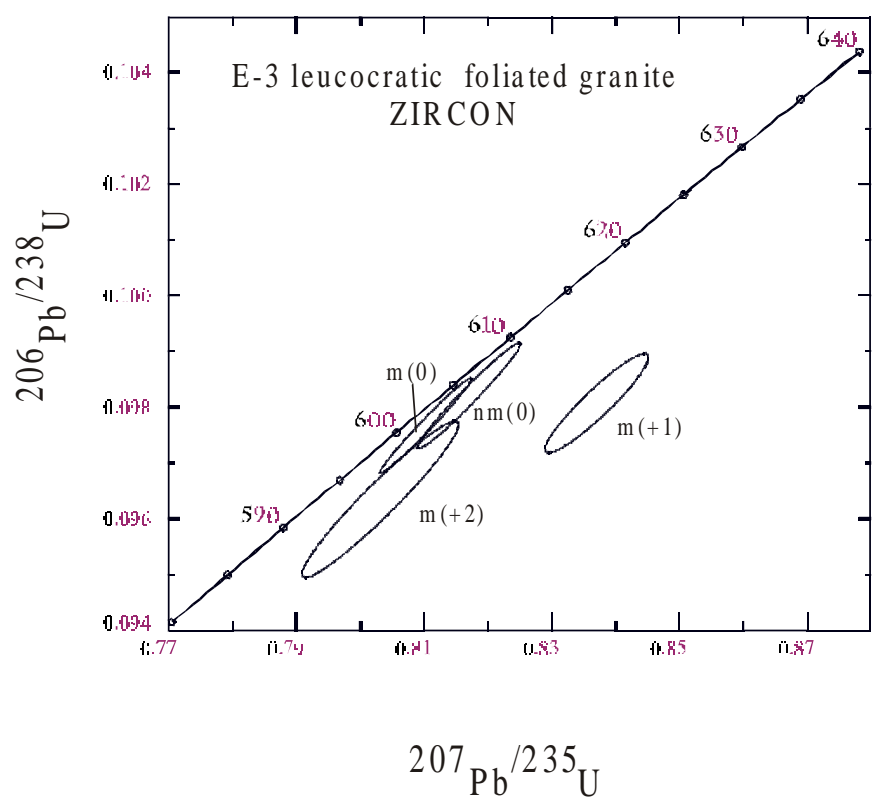

Figure 4- U-Pb concordia diagram for sample E-3.

Table 1-Results of U-Pb isotope determinations for granites of the Três Córregos Batholith.

\begin{tabular}{|c|c|c|c|c|c|c|c|c|c|c|c|c|c|}
\hline & \multirow{2}{*}{$\begin{array}{l}\text { Size } \\
(\mathrm{mg})\end{array}$} & \multirow{2}{*}{$\begin{array}{c}\mathbf{P b} \\
(\mathbf{p p m})\end{array}$} & \multirow{2}{*}{$\begin{array}{c}\mathrm{U} \\
(\mathbf{p p m})\end{array}$} & \multicolumn{3}{|c|}{ Final corrected ratios } & \multirow[b]{2}{*}{$\begin{array}{c}\% \\
\text { error }\end{array}$} & \multirow[b]{2}{*}{${ }^{207} \mathrm{~Pb} /{ }^{206} \mathrm{~Pb}$} & \multicolumn{2}{|c|}{ Ages (Ma) } & \multirow[b]{2}{*}{${ }^{207} \mathrm{~Pb} /{ }^{206} \mathrm{~Pb}$} & \multirow[b]{2}{*}{$+/-$} \\
\hline description & Fraction & & & & $\begin{array}{c}{ }^{206} \mathrm{~Pb} / \\
{ }^{238} \mathrm{U}\end{array}$ & $\begin{array}{c}\% \\
\text { error }\end{array}$ & $\begin{array}{c}{ }^{207} \mathrm{~Pb} / \\
{ }^{235} \mathrm{U}\end{array}$ & & & $\begin{array}{c}{ }^{206} \mathrm{~Pb} / \\
{ }^{238} \mathrm{U}\end{array}$ & ${ }^{2075} \mathrm{~Pb} /$ & & \\
\hline \multicolumn{14}{|c|}{ S-1 Hbl-Bt granite } \\
\hline $8 \mathrm{~g}, \mathrm{tr}, \mathrm{pr}$ & $\mathrm{nm}(0)$ & 0.008 & 60.6 & 528.8 & 0.09653 & 1.20 & 0.80028 & 1.23 & 0.06013 & 594.1 & 597.0 & 608.1 & 5.0 \\
\hline $10 \mathrm{~g}, \mathrm{tr}, \mathrm{pr}$ & $\mathrm{m}(0)$ & 0.027 & 74.2 & 647.3 & 0.09784 & 0.71 & 0.80984 & 0.73 & 0.06003 & 601.7 & 602.4 & 604.8 & 3.1 \\
\hline $12 \mathrm{~g}, \mathrm{tr}, \mathrm{pr}, \mathrm{lg}$ & $\mathrm{m}(1)$ & 0.012 & 65.1 & 580.6 & 0.09227 & 0.84 & 0.76388 & 0.88 & 0.06004 & 568.9 & 576.3 & 605.2 & 5.2 \\
\hline $6 \mathrm{~g}, \mathrm{sm}, \mathrm{pr}$ & $\mathrm{m}(+1)$ & 0.011 & 52.4 & 446.3 & 0.09725 & 1.04 & 0.80437 & 1.07 & 0.05999 & 598.3 & 599.3 & 603.1 & 4.6 \\
\hline \multicolumn{14}{|c|}{ E-3 leucocratic foliated granite } \\
\hline pr,na & $\mathrm{nm}(0)$ & 0.014 & 56.6 & 507.8 & 0.09820 & 0.79 & 0.81699 & 0.81 & 0.06034 & 603.9 & 606.4 & 615.7 & 3.6 \\
\hline $5 \mathrm{~g}, \mathrm{pr}, \mathrm{na}$ & $\mathrm{m}(0)$ & 0.014 & 61.4 & 603.0 & 0.09767 & 0.71 & 0.81024 & 0.72 & 0.06017 & 600.8 & 602.6 & 609.5 & 2.7 \\
\hline pr,na & $\mathrm{m}(+1)$ & 0.012 & 68.8 & 667.3 & 0.09807 & 0.74 & 0.83706 & 0.79 & 0.06190 & 603.1 & 617.5 & 670.7 & 6.2 \\
\hline pr,na & $\mathrm{m}(+2)$ & 0.010 & 41.7 & 416.5 & 0.09635 & 1.19 & 0.80313 & 1.25 & 0.06045 & 593.0 & 598.6 & 619.9 & 7.7 \\
\hline \multicolumn{14}{|c|}{ MN-15 Hbl-Bt gneiss } \\
\hline $3 g, t r, p r, l g$ & $\mathrm{~m}(-1) \lg$ & 0.009 & 49.0 & 357.6 & 0.13145 & 1.17 & 1.48773 & 1.19 & 0.08291 & 788.7 & 925.4 & 1267.0 & 4.3 \\
\hline $8 \mathrm{~g}, \mathrm{tr}, \mathrm{pr}$ & $\mathrm{m}(-1)$ & 0.011 & 45.2 & 479.1 & 0.09413 & 0.99 & 0.78027 & 1.02 & 0.06012 & 579.9 & 585.6 & 607.9 & 4.9 \\
\hline $9 \mathrm{~g}, \mathrm{tr}, \mathrm{pr}$ & $\mathrm{m}(0)$ & 0.018 & 59.2 & 527.7 & 0.09506 & 0.62 & 0.79082 & 0.63 & 0.06034 & 585.4 & 591.6 & 615.7 & 2.8 \\
\hline pr,na & $\mathrm{m}(+1)$ & 0.008 & 12.1 & 96.9 & 0.10169 & 5.42 & 0.84340 & 5.54 & 0.06015 & 624.3 & 621.0 & 609.0 & 21.0 \\
\hline
\end{tabular}

$\mathrm{G}=$ grain $; \mathrm{tr}=$ transparent, $\mathrm{pr}=$ prismatic, $\mathrm{lg}=$ large, $\mathrm{sm}=$ small, $\mathrm{na}=$ non-abraded, $\mathrm{Hbl}=$ hornblende, $\mathrm{Bt}=$ biotite . 


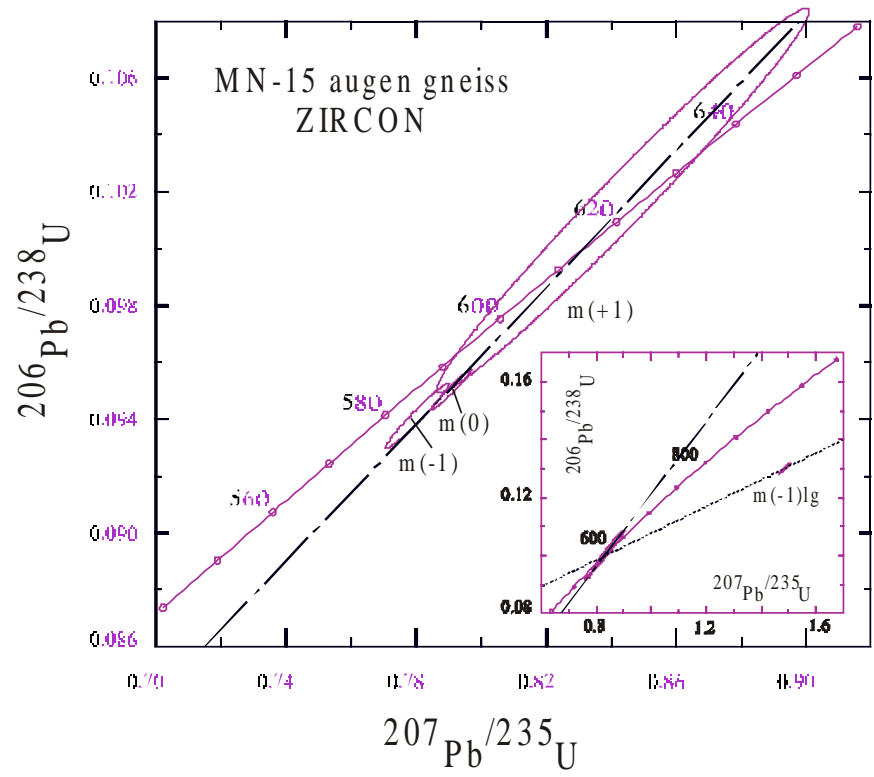

Figure 5- U-Pb concordia diagram for sample MN-15; inset shows fraction $m(-1) l g$, with a high inherited component.

1993, Reis Neto 1994). The result however leaves no doubt on its reliability, and is further reinforced by the U-Pb ages recently obtained for petrographically similar syn-orogenic granites from the neighboring Agudos Grandes Batholith (ca. $610 \pm 2 \mathrm{Ma}$; Janasi et al., 2000).

Although an equally precise age could not be determined for the other two samples studied (E-3 and MN-15) because of problems with inheritance, the data herein reported provide important clues to the batholith stratigraphy. The upper limit of 608-610 Ma determined for the crystallization age of both samples clearly indicates that they are related to the same event that built up the bulk of the batholith, and most probably have undistinguishable ages, within error, from those of the Saival granite. Their foliated character should thus reflect differences in the partition of the strain on a regional scale during or shortly after the crystallization of the magmas, and not a pre-tectonic character. This is particularly significant for the augen-gneiss sample MN-15 to which a Transamazonian age was admitted up to now.

Rb-Sr ISOTOPE GEOCHEMISTRY In an early attempt to know the crystallization age of the syn-orogenic granites of the Três Córregos Batholith, an extensive program of $\mathrm{Rb}-\mathrm{Sr}$ isotope determinations was carried out at the Centro de Pesquisas Geocronológicas (CPGeo), Instituto de Geociências, Universidade de São Paulo, Brazil (see Gimenez Filho 1993 and Tassinari 1988 for details of the analytical procedures at CPGeo in the early 90s).

Outcrop isochrons were targeted, but all of them resulted in very imprecise ages owing mainly to the small scattering on the $\mathrm{Rb} / \mathrm{Sr}$ ratios. Ages between 790 and $660 \mathrm{Ma}$, with errors tipically above 60 $\mathrm{Ma}$, were calculated for different sets of granite samples (Fig. 6).

In the approach here adopted, the $\mathrm{Rb}-\mathrm{Sr}$ isotope results are used as a tool to investigate petrological processes affecting the magmas of the Três Córregos Batholith, including the understanding of the causes why they yield ages older than those of magmatic crystallization as given by the U-Pb method. For that purpose, the ${ }^{87} \mathrm{Sr} /{ }^{86} \mathrm{Sr}$ ratios were calculated at the age of crystallization, assumed to be $605 \mathrm{Ma}$ for all samples (Table 2).

Analytical results are available for three different occurrences of syn-orogenic granites: porphyritic granites of the Barra do Chapéu and Córrego do Butiá massifs and foliated granites cropping out at the NE end of the studied area, which might correspond to a border facies of the Paiol de Telha massif (Figure 2). A significant scatter of the ${ }^{87} \mathrm{Sr} /$ ${ }^{86} \mathrm{Sr}_{605}$ ratios, of 0.002-0.003 units, well above the analytical error (Table 2), is observed in each of the three occurrences, and responds for the wide scatter of the data in isochronic diagrams (Fig. 6).

If all three massifs are considered together, the result is a remarkable negative correlation between the Sr content of the rock and its ${ }^{87} \mathrm{Sr} /{ }^{86} \mathrm{Sr}_{605}$ ratio (Fig. 7). This is consistent with a petrological evolution in which a more mafic, Sr-rich magma (such as the
Table 2-Results of Rb-Sr isotope for granites of the Três Córregos Batholith. CB samples are from Souza (1990).

\begin{tabular}{|c|c|c|c|c|c|c|c|c|}
\hline $\begin{array}{l}\text { Lab. } \\
\text { Number }\end{array}$ & $\begin{array}{c}\text { Field } \\
\text { Number }\end{array}$ & $\begin{array}{c}\mathbf{R b} \\
(\mathbf{p p m})\end{array}$ & \begin{tabular}{c|}
$\mathbf{S r}$ \\
$(\mathbf{p p m})$
\end{tabular} & ${ }^{87} \mathrm{Rb}{ }^{86} \mathrm{Sr}$ & error & ${ }^{87} \mathrm{Sr} /{ }^{86} \mathrm{Sr}$ & error & ${ }^{87} \mathrm{Sr} /{ }^{86} \mathrm{Sr}_{60}$ \\
\hline \multicolumn{9}{|c|}{ Paiol de Telha foliated granites } \\
\hline 11633 & AM1 & 135.86 & 595.95 & 0.6606 & 0.0134 & 0.71990 & 0.00005 & 0.71420 \\
\hline 11634 & AM3a & 161.60 & 582.60 & 0.8040 & 0.0230 & 0.72240 & 0.00005 & 0.71546 \\
\hline 11615 & AM4a & 126.72 & 612.52 & 0.5995 & 0.0106 & 0.72022 & 0.00009 & 0.71505 \\
\hline 11616 & $\mathrm{AM} 4 \mathrm{e}$ & 141.78 & 641.18 & 0.6413 & 0.0108 & 0.72005 & 0.00006 & 0.71452 \\
\hline 11617 & AM4f & 140.79 & 642.96 & 0.6345 & 0.0110 & 0.71984 & 0.00010 & 0.71437 \\
\hline 11618 & AM4h & 151.26 & 570.05 & 0.7690 & 0.0129 & 0.72105 & 0.00007 & 0.71442 \\
\hline \multicolumn{9}{|c|}{$\begin{array}{l}\text { Córrego do Butiá } \\
\text { granites }\end{array}$} \\
\hline 11440 & B5 & 145.0 & 446.0 & 0.942 & 0.027 & 0.72398 & 0.00009 & 0.71585 \\
\hline 11441 & B6 & 137.6 & 459.0 & 0.869 & 0.025 & 0.72471 & 0.00009 & 0.71721 \\
\hline 11442 & B8 & 146.9 & 507.6 & 0.839 & 0.024 & 0.72419 & 0.00008 & 0.71695 \\
\hline 11443 & B11 & 172.3 & 433.6 & 1.152 & 0.033 & 0.72494 & 0.00006 & 0.71500 \\
\hline 9640 & CB3 & 150.6 & 444.2 & 0.983 & 0.028 & 0.72538 & 0.00005 & 0.71699 \\
\hline 9641 & CB6 & 124.8 & 471.6 & 0.767 & 0.022 & 0.72304 & 0.00006 & 0.71642 \\
\hline 9642 & & 177.3 & 485.8 & & 0.030 & & 0.00005 & 1678 \\
\hline 9643 & CB9 & 155 & 473.5 & 953 & 0.027 & 0.72472 & 0.00005 & 0.71650 \\
\hline 9644 & CB 12 & 172.1 & 427.6 & 1.167 & 0.033 & 0.72647 & 0.00005 & 0.71640 \\
\hline \multicolumn{9}{|c|}{$\begin{array}{l}\text { Barra do Chapéu } \\
\text { granites }\end{array}$} \\
\hline 11630 & ET48 & 214.44 & 759.88 & 0.8170 & 0.0113 & 0.71754 & 0.00009 & 0.71049 \\
\hline 11631 & ET49 & 141.53 & 717.42 & 0.5715 & 0.0096 & 0.71787 & 0.00005 & 0.71294 \\
\hline 11632 & ET53 & 134.00 & 577.70 & 0.6720 & 0.0190 & 0.71842 & 0.00007 & 0.71262 \\
\hline 11637 & ET54 & 193.41 & 756.22 & 0.7490 & 0.0103 & 0.71740 & 0.00005 & 0.71094 \\
\hline 11638 & ET55 & 183.37 & 855.32 & 0.6210 & 0.0086 & 0.71671 & 0.00005 & 0.71135 \\
\hline \multicolumn{9}{|c|}{$\begin{array}{l}\text { Barra do Chapéu } \\
\text { enclaves }\end{array}$} \\
\hline 11572 & ET18 & 93.02 & $\begin{array}{r}1004.5 \\
7\end{array}$ & 0.2682 & 0.0045 & 0.71585 & 0.00006 & 0.71354 \\
\hline 11573 & ET19 & 94.60 & 791.81 & 0.3461 & 0.0058 & 0.71690 & 0.00007 & 0.71394 \\
\hline 11574 & ET23 & 56.07 & 850.16 & 0.1910 & 0.0032 & 0.71640 & 0.00010 & 0.71475 \\
\hline 11575 & ET26 & 57.43 & 945.01 & 0.1760 & 0.0029 & 0.71612 & 0.00006 & 0.71460 \\
\hline 11731 & ET28 & 44.04 & 725.65 & 0.3714 & 0.0051 & 0.71638 & 0.00008 & 0.71318 \\
\hline 11636 & ET51 & 114.27 & 867.82 & 0.3814 & 0.0066 & 0.71656 & 0.00005 & 0.71270 \\
\hline \multicolumn{9}{|c|}{ Other mafic enclaves } \\
\hline 11623 & GD $1 b$ & 80.99 & 821.01 & 0.2857 & 0.0048 & 0.71521 & 0.00006 & 0.71275 \\
\hline 11624 & GD1d & 72.47 & $\begin{array}{r}1048.6 \\
9\end{array}$ & 0.2001 & 0.0034 & 0.71489 & 0.00008 & 0.71316 \\
\hline 11625 & GD1f & 116.55 & 749.55 & 0.4564 & 0.0080 & 0.71616 & 0.00005 & 0.71222 \\
\hline 11626 & GD1g & 100.17 & 835.50 & 0.3472 & 0.0059 & 0.71542 & 0.00006 & 0.71242 \\
\hline 11627 & GD2b & 120.55 & 794.46 & 0.4396 & 0.0074 & 0.71863 & 0.00006 & 0.71484 \\
\hline 11628 & GD2d & 149.77 & 654.45 & 0.6631 & 0.0112 & 0.71977 & 0.00006 & 0.71405 \\
\hline 11629 & GD2e & 133.07 & 800.76 & 0.4815 & 0.0081 & 0.71866 & 0.00007 & 0.71451 \\
\hline
\end{tabular}

hornblende-biotite Barra do Chapéu granite) is progressively contaminated by a low-Sr, high time-integrated $\mathrm{Rb} / \mathrm{Sr}$ felsic material (crust-derived melts), resulting in more felsic magmas with higher ${ }^{87} \mathrm{Sr} /{ }^{86} \mathrm{Sr}_{605}$ (such as the Córrego do Butiá granites). As shown by several authors (Vlach \& Cordani 1986, Heaman \& Smalley 1994), $\mathrm{Rb}-\mathrm{Sr}$ isochronic ages older than the age of magmatic crystallization of a granite are frequently the result of such mixing processes (i.e., where there is a positive correlation between the $\mathrm{Rb} / \mathrm{Sr}$ and the ${ }^{87} \mathrm{Sr}^{86} \mathrm{Sr}_{i}$ ratios of the magmas).

Geochemical data are not available so far for many of the rocks analysed for $\mathrm{Rb}$ and $\mathrm{Sr}$ isotopes. In particular, only one analysis exists for the more differentiated Córrego do Butiá granites (Gimenez Filho et al. 1995). A new program of lithogeochemical analyses is underway on these samples to test quantitatively the above hypothesis.

A somewhat unusual behavior of the $\mathrm{Rb} / \mathrm{Sr}$ isotopic system is shown by the mafic ("dioritic") enclaves, marked by a positive correlation between the $\mathrm{Sr}$ contents and the ${ }^{87} \mathrm{Sr} /{ }^{86} \mathrm{Sr}_{\mathrm{i}}$ ratios (Table 2; Fig. 7). This is very clear when the whole set of samples from the Barra do Chapéu massif (granites and enclaves, all from the same outcrop) is considered. Although more subtle, this correlation is also evident in the two sets of GD samples (Fig. 7, Table 2).

A possible explanation for this behavior is that a high ${ }^{87} \mathrm{Sr} /{ }^{86} \mathrm{Sr}$ ratio is a feature of a mantle-derived, basic component represented by the enclaves, and that granites such as those of the Barra do Chapéu 

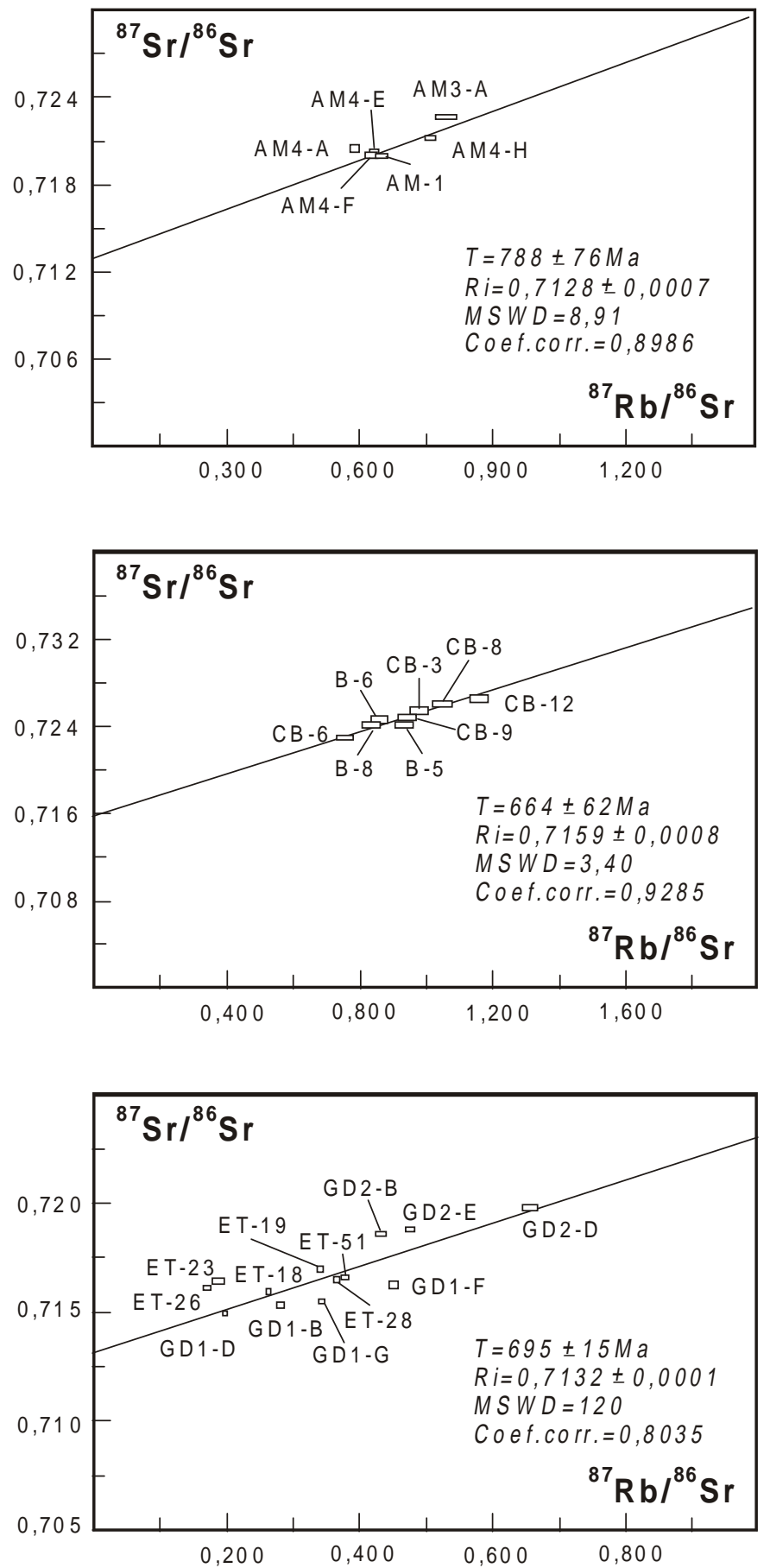

Figure 6- Rb-Sr isochronic diagrams for selected occurrences of the Três Córregos Batholith.

massif are hybrids between these magmas and crustal magmas derived from a (granulitic?) lower crust poorer in $\mathrm{Sr}$ and with low timeintegrated $\mathrm{Rb} / \mathrm{Sr}$ ratios. The spread seen in the enclave data in Figure 7 could result from contamination with both this low $\mathrm{Rb} / \mathrm{Sr}$-medium $\mathrm{Sr}$ lower-crust component and the high $\mathrm{Rb} / \mathrm{Sr}$-low $\mathrm{Sr}$ (intermediatecrust?) component identified in the more felsic granites. Also in this case, a more complete geochemical dataset is being obtained to test the interpretation proposed here.

CONCLUSIONS The U-Pb zircon age of sample S-15 (605.1 \pm $2.0 \mathrm{Ma}$ ) is interpreted as the best estimate of the crystallization age of the typical porphyritic hornblende-biotite granites that make up the Três Córregos Batholith in the studied region. The upper age limits obtained for a foliated granite (sample E-3) and an augen-gneiss (sample MN-15) (both at ca. 608-610 Ma) make it evident that these rocks are products of the same magmatism that generated the bulk of

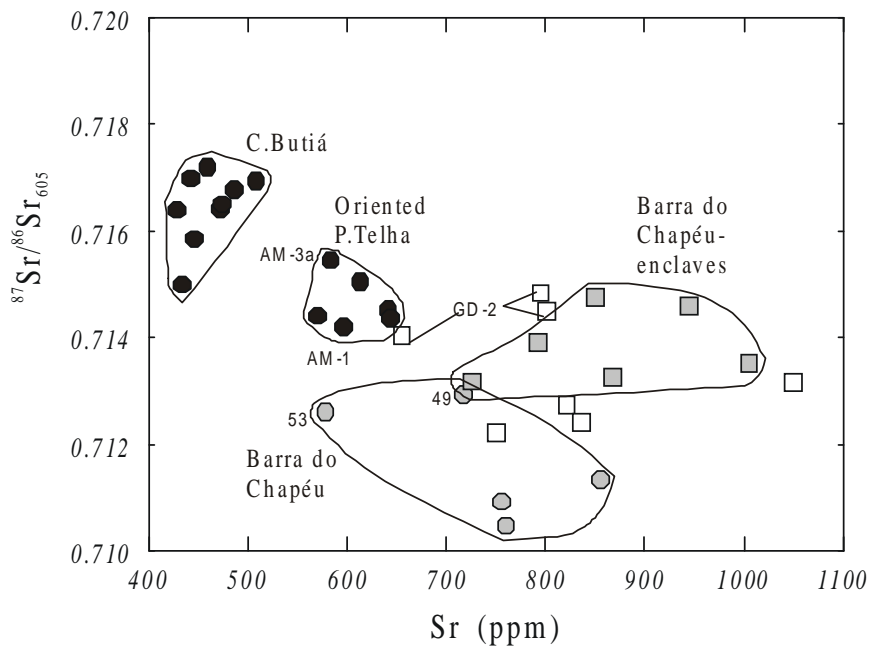

Figure 7- ${ }^{87} \mathrm{Sr}^{86} \mathrm{Sr}_{605}$ vs. Sr contents (ppm) of rocks of the Três Córregos Batholith. Symbols: Circles= granites (grey= Barra do Chapéu massif; closed= Corrego do Butiá and Paiol de Telha massifs); squares= mafic finegrained enclaves (grey= Barra do Chapéu massif; open= samples GD-1 and GD-2). For other sample identification, refer to Table 2.

the batholith, and not part of old basement sequences as suggested in some earlier works.

Recently obtained U-Pb data in the neighboring Agudos Grandes Batholith (Janasi et al. 2000) point to a similar age for equivalent granites $(610 \pm 2 \mathrm{Ma}$ in the porphyritic hornblende-biotite Ibiúna granite type). Some of the proposed models for the age and duration of the "syn-orogenic" period in the Três Córregos and Agudos Grandes batholiths are based on previous $\mathrm{Rb}-\mathrm{Sr}$ dating that yielded ages varying from 640 to 780 Ma (Souza 1990, Gimenez Filho 1993, Reis Neto 1994, Leite 1997). Apart from the large errors involved (of $50 \mathrm{Ma}$ or more), doubts have been raised about the significance of these results, that remained in unpublished thesis.

The U-Pb results presented here and elsewhere (Janasi et al. 2000) point to a much shorter duration ( $<10 \mathrm{Ma}$ ?) and a slightly younger age than previously attributed to the "syn-orogenic" period in the Três Córregos and Agudos Grandes batholiths.

The reassesment of the Rb-Sr data of Gimenez Filho (1993) for the Três Córregos batholith suggests that the anomalous isochronic ages obtained in the $\mathrm{Rb}-\mathrm{Sr}$ system could be explained as a result of a systematic variation on the ${ }^{87} \mathrm{Sr} /{ }^{86} \mathrm{Sr}$ initial ratio, that seems to show a positive correlation, in a batholith scale, with the $\mathrm{Rb} / \mathrm{Sr}$ ratio. Such correlation could reflect a progressive contamination of more mafic, Sr-rich granitic magmas by felsic crustal melts having high timeintegrated $\mathrm{Rb} / \mathrm{Sr}$. Thus, once precise assumptions about the crystallization ages of these granites can be made, the existing $\mathrm{Rb}-\mathrm{Sr}$ isotope datasets can be used as powerful tools to unravel their petrogenetic evolution. In the case of the Três Córregos Batholith, the nature of the very high ${ }^{87} \mathrm{Sr} /{ }^{86} \mathrm{Sr}$ initial ratios of the $\mathrm{Sr}$-rich mafic dioritic enclaves, possibly a result of enriched sources in the mantle, is one of the most intriguing features that needs further investigation.

$\mathrm{No}$ U-Pb dates exist so far for the late, "post-orogenic" granitic plutons that intrude the Três Córregos Batholith, such as the Sguario and Correas massifs. Gimenez Filho (1993) obtained Rb-Sr isochronic ages clearly too young (respectively, $523 \pm 21 \mathrm{Ma}$ and $480 \pm 19 \mathrm{Ma}$ ), since $\mathrm{K}$-Ar ages on biotites from the same samples yielded older ages, in the 560-600 Ma range. Goraieb (1995) presented a well-fitted 603 $\pm 7 \mathrm{Ma} \mathrm{Rb}$-Sr isochron for topaz-bearing albite granites of the Correas massif. If this is the age of the magmatic crystallization of the massif, then a negligible time-span between the intrusion of the "postorogenic" massifs and the bulk of the batholith would be implied.

The isotope data presented here and elsewhere (Reis Neto 1994) place important constraints on the tectonic significance of the Três Córregos Batholith within the RFB. As also shown by the ages of the Agudos Grandes Batholith, the syn-orogenic period in this portion of the RFB seems to be slightly older than observed to the north, in the states of Rio de Janeiro and Espírito Santo (590-565 Ma; Machado et al. 1996). The inferred contributions from enriched lithospheric mantle and old crust clearly indicate that, if subduction-related as admitted in the literature (e.g., Wernick et al. 1990, Gimenez Filho 1993, Gimenez 
Filho et al. 1995, Reis Neto 1994), the batholith was a part of a magmatic arc developped within a continental crust.

Acknowledgements To Dr. W. R. van Schmus, for training and allowing one of us (V.A.J.) to use the facilities of the Isotope
Geochemistry Laboratory (IGL) at the University of Kansas, USA, for $\mathrm{U}-\mathrm{Pb}$ analyses. FAPESP financed the visit to IGL (Proc. 97/2438-9) and the first author's Master Dissertation (Proc. 88/3806-2). To two anonymous referees of RBG for the critical analysis of the manuscript

\section{References}

Campanha G. A da C. \& Sadowski G. R. 1999. Tectonics of the southern portion of the Ribeira Belt (Apiaí Domain). Precambrian Research, 98:31-51.

Gimenez Filho A. 1993. Evolução do Complexo Granítico de Três Córregos, a noroeste de Apiaí- SP. Instituto de Geociências, Universidade de São Paulo, Dissertação de Mestrado, $118 \mathrm{p}$.

Gimenez Filho A., Teixeira W., Figueiredo M. C. H., Trevizoli Jr. L. 1995 Geologia, Petrografia e litogeoquímica do Complexo Granítico Três Córregos na região de Barra do Chapéu e Ribeirão Branco, SP. Revista Brasileira de Geociências 25.92 106.

Goraieb C.L. 1995. Aspectos geológicos e metalogenéticos do maciço Correas. Instituto de Geociências, Universidade de São Paulo, Dissertação de Mestrado, 150 p, anexos.

Heaman L.M. \& Smalley P.C. 1994. A U-Pb study of the Morkheia Comple gneisses, southern Norway: Implications for disturbed $\mathrm{Rb}-\mathrm{Sr}$ systems and for the temporal evolution of Mesoproterozoic magmatism in Laurentia. Geochimica et Cosmochimica Acta, 58:1899-1911.

Janasi V.A. \& Ulbrich H.H.G.J., 1991. Late Proterozoic granitoid magmatism in the State of São Paulo, southeastern Brazil. Precambrian Research, 51:351-374.

Janasi V.A., Vasconcellos A.C.B.C., Vlach, S.R.F. \& Motidome M.J. 1990. Granitóides da região entre as cidades de São Paulo e Piedade (SP): faciologia e contexto tectônico. In: SBG, Congresso Brasileiro de Geologia, 36, Natal-RN, Anais, 4:1925-1935.

Janasi V.A., Leite R.J. \& van Schmus W.R. 2000. U-Pb ages and stratigraphy of the granitic magmatism in the Agudos Grandes Batholith (W of São Paulo, Brazil) - implications for the evolution of the Ribeira Belt. Journal of South American Earth Sciences (submitted)

Leite R.J. 1997. Geologia, petrografia e geoquímica dos granitos da região de Piedade $(S P)$. Instituto de Geociências, Universidade de São Paulo, Dissertação de Mestrado, $138 \mathrm{p}$.
Machado N., Valladares C., Heilbron M. \& Valeriano C. 1996. U-Pb geochronology of the central Ribeira belt (Brazil) and implications for the evolution of the Brazilian Orogeny. Precambrian Research, 79:347-361.

Reis Neto J.M. 1994. Faixa Itaiacoca: registro de uma colisão entre dois blocos continentais no Neoproterozóico. Instituto de Geociências, Universidade de São Paulo, Tese de Doutoramento, $253 \mathrm{p}$

Ribeiro A., Trouw R.A.J., Andreis R.R., Paciullo F.V.P. \& Valença, J.G. 1995. Evolução das bacias Proterozóicas e o termo-tectonismo brasiliano na margem sul do Cráton São Francisco. Revista Brasileira de Geociências, 25:235-248.

Souza A.P. 1990. Mapa geológico na escala 1:50.000 e esboço da evolução tectônica e sedimentar do Grupo Itaiacoca, nas Folhas Barra do Chapéu e Ouro Verde-SP/PR. sedimentar do Grupo Itaiacoca, nas Folhas Barra do Chapéu e Ouro Verde-SP/PR.

Tassinari C.C.G. 1988. As idades das rochas e dos eventos metamórficos da porção sudeste do Estado de São Paulo e sua evolução crustal. Instituto de Geociências, Universidade de São Paulo, Tese de Doutoramento, $236 \mathrm{p}$

Vlach S.R.F. \& Cordani U.G. 1986. A sistemática Rb/Sr em rochas granitóides: considerações interpretativas, limitações e exemplos brasileiros. Revista Brasileira de Geociências, 16:38-53.

Wernick E., Galembeck T.M.B., Rigo Jr. L., Artur A.C. \& Weber-Diefenbach K. 1990. O Complexos Granitóides Cunhaporanga e Três Córregos (PR): zoneamento magmático e implicações geotectônicas. Geociências, Rio Claro-SP, 9:67-85.

Contribution IGC-079

Received February 25, 2000 Accepted for publication April 30, 2000 